\title{
Social Science or Islamic Education
}

\author{
Erlanda Saleh ${ }^{1}$, Lukman Hakim $^{2}$, Edi Jatmiko ${ }^{3}$, Marfudin $^{4}$ \\ \{erlandasaleh888penmad@gmai.com ${ }^{1}$, uman.alhakim2@gmail.com², Mikogie1@mail.com ${ }^{3}$, \\ Marfudin211@gmail.com ${ }^{4}$ \}
}

${ }^{1,2,3,4}$ Graduate School, State Institute for Islamic Studies of Metro, Indonesia

\begin{abstract}
Judging from its function in human life, religion is required to be able to reformulate (think) ideas clearly and systematically so that humanizing humans becomes more focused. It can be concluded that Islam has good quality but in its implementation a social approach is still needed. knowledge in Islamic studies, namely, Sociology, Anthropology, Gender, History, Semantics, Philology, and so on. But currently only two approaches will be adopted, namely the sociological and anthropological approaches.
\end{abstract}

Keywords: sociological and anthropological approaches.

\section{Introduction}

Humans live have 2 (two) roles at once namely as individual beings and also social beings. The word "individual" comes from the word in and devided. In English in one of them contains the meaning no, while devided means divided. So individual meaning is not divided, or unity. In Latin the individual comes from the word individium which means the undivided, so it is a term that can be used to express a smallest and infinite unity. Meanwhile, as social beings, humans cannot live alone, they always need the help of others in fulfilling their needs. ${ }^{[1]}$ Islam as a religion that rahmatan lil'alaimin is not only oriented towards vertical relations but also horizontally. Because the transgression of humans is not only indicated by vertical relations with God but also the horizontal relations of individuals with other individuals. Even in the Qur'an itself the relationship between human beings is more explained than with their God (tawhid). So this is where the importance of learning social science approaches in understanding Islam, especially Islamic studies.

There are several approaches to the social sciences in Islamic studies, namely, Sociology, Anthropology, Gender, History, Semantics, Philology, and so on. But this time only two approaches will be adopted, namely the sociology and anthropology approaches.

\subsection{Sociology Approach}

Sociology in a broad sense is the study of society and the social symptoms that occur in society. [2] Sociology as a biological child modernity is born in order to understand social life and how people act in it.The sociology approach can be used as a tool in understanding religious teachings because many of the religious studies can only be understood proportionally and appropriately when using a sociological approach. In the book "Alternative Islam" written by Jalaluddin Rahmat, it was stated that Islam is so concerned with social issues.

As for what needs to be considered in studying Islamic studies through a sociological approach, lies in its function in society.[3] Judging from its function in human life, religion is required to be able to reformulate (reconstruct) its thoughts clearly and systematically in order to humanize humans to be more directed. 
Quantitatively, every adherent of Islam is required to have his own awareness in determining or choosing his religion, namely by first analyzing and studying the religion of his choice. But that reality is only carried out by intellectuals while the laity is only a small proportion who have such willingness. It can be concluded that Islam has good quality but its followers lack or even lack quality. Sad enough isn't it?

Therefore, the study of Islam in sociological approaches is seen as very important to achieve a broad and comprehensive understanding (kafah) of Islamic studies. This is done specifically so that ordinary people can also apply quality Islamic studies.

\subsection{Anthropological Approach}

Anthropology can simply be interpreted as a study of society and culture. Culture itself is the result of human inner activities and creation.

Anthropological approaches to understanding Islamic studies can be seen in the form of religious practices/rituals that grow and develop in society. The anthropological approach in Islamic studies means a reasonable approach used in conducting cultural approach research that does not violate the prevailing norms in Islam.

Anthropology as an approach in studying Islamic studies can be clarified into several parts including:

1. Phenomenological anthropological approach; this approach can see the relationship betweenreligion and state.

2. An anthropological approach to the relationship between religion and psychotherapy.

3. An anthropological approach that relates between religion and organizing mechanisms.

In clarifying the above, it is clear that religion is very closely related to the branches of anthropology, so that in this case religion can connect functionally with various phenomena of human life.

\section{Formulation Of The Problem}

From the description above it is clear that in the concept of Islam there really is no separation between social science and Islamic education. The method used through the anthropological approach is a holistic method, meaning that in seeing a social phenomenon must be examined in the context of the totality of the culture of society being studied. While the data collection techniques use the method of observation and in-depth interviews (plunging directly into the community) and literature books so that in this case the writer takes the subject matter, that is:

1. How is the relationship between people in life?

2. Humans are often trapped in scientific arrogance?

\section{Discussion}

\subsection{How is the positive relationship between religious beliefs and economic conditions}

According to the fuqaha, property in an Islamic perspective is based on two elements; First, the 'aniyyah element and Second, the" urf element. The 'aniyyah element is that the treasure has a form in reality (a'yun). While the 'urf element is anything that is considered a treasure by all people or by some humans, not humans maintain something except wanting the benefits, Both benefits that are madiyyah or ma'nawiyyah[4]. In fact the first principle in building an Islamic economy is to respect the value of property and its role in human life. Because the assumptions that circulated before the arrival of Islam, 
either as an understanding of religion or flow, have considered wealth as evil, while poverty is considered as goodness, even considering everything related to material enjoyment is dirt for the spirit and an obstacle to the increase in spiritual glory. That is how it is known in the Brahma philosophy in India and in the Manawi sect 'in Paris, as it is also known in Christianity. This tendency is increasingly apparent in the monastic system (priesthood). ${ }^{[5]}$ The owners of the Gospels (Matthew, Marcus, and Luke) tell from the Messiah, "That there really is a rich young man who wants to follow Christ and wants to enter his religion, then the Messiah says to him," Sell your possessions and then give them from the proceeds of the sale were to fuqara 'and come follow me. "So when it was hard for the young man, the Messiah said," It is difficult for rich people to enter the kingdom of heaven! I also say to you, "Truly the entry of camels into the eye of the needle is easier, than the entry of the rich into the kingdom of God. [6] "New streams (materialism) such as Materialists and Socialists, they make the economy as a life goal and make property their Lord for individuals and society. [7]

In addition, the acquisition of assets carried out does not cause the perpetrators to be negligent about other syar'i delinquencies, such as forgetting dhikrullah (not remembering Allah with all His provisions) (al-Munafiqun: 9), forgetting prayer and zakat (an-Nur: 37), as well as other obligations related to transindent relationships and social life (hablul min Allah and hablul mi an-Nas). it can be concluded that in society, religion plays an important role as a counterweight to people's lives, as a reference or basis for the community in socializing and religion is able to unite all the differences that exist in society. because it is inevitable that we, as citizens of Indonesia, must know that Indonesia has a variety of cultures, ethnicities, ethnicities, and even religions so that it is hoped that religion will be able to carry out its role in society well so as to create a peaceful, peaceful, secure, stable society.

According to Johnstone [8] religion is a system of belief and practice as a means for a group of people to interpret and respond to what they feel as supernatural and holy beings. Religion as a belief system serves as a source of guidance for people in thinking and interpreting things. Meanwhile, religion as a system of practice serves as a guide for adherents in acting or responding to various stimuli they face. Human belief in something that is supernatural becomes a tendency that directs humans to the harmonious social order of society. Meanwhile according to Emile Durkheim [9] religion is a system of symbols through which people become aware of themselves. Durkheim argues that religion symbolically embodies society itself. Durkheim sees religious beliefs as representations that reveal the nature of sacred things and the relationships they maintain both with one another and with the world. According to him religion in a society in a nonmodern society is a collective conscience that is all encompassing. The main function of religion according to William Haviland is to reduce. Anxiety and establish confidence in oneself and maintain the human condition so that it is ready to face reality [10]. Religion is one of the social institutions in society which consists of the organization of thought patterns and patterns of human behavior that are manifested through various social activities and worship. Religion as a social institution basically is a set of norms of all levels that revolve around a basic need in people's lives. Besides that, religion as a social institution has certain symbols, tools, traditions and goals. According to Soerjono Soekanto, [11] social institutions that aim to meet basic human needs basically have several functions, namely: 1) As a guide to community members, how they should behave or behave; 2) Maintaining the integrity of the community; 3). Gives a handle to community members to carry out social control. Religious life is basically a belief in the belief in the existence of supernatural, supernatural or supernatural powers that affect the lives of individuals and society. ${ }^{[12]}$ Religion governs every aspect of society's life, including one of them is economic life. The economy itself is an effort in decision making and its implementation which is related to the allocation of limited household resources among various members by considering, their abilities, efforts and desires [13]. In this case, religion provides guidelines that regulate and limit various economic actions that are considered good and considered bad by religious teachings. Religion determines what economic actions may be carried out and economic actions that may not be carried out 
by its adherents in daily life. For example in Islamic religion, socioeconomic actions such as "buying and selling" are permissible, but on the other hand Islam also provides restrictions on the forms of trading that are allowed. Islam forbids forms of buying and selling illicit goods such as liquor and drugs. That is, in carrying out economic activity every religious adherent is always encouraged to pay attention to the halal and haram norms contained in the religion.

\subsection{Humans are often trapped in scientific arrogance}

Islam teaches faith in Allah Almighty and the Prophet Muhammad, who is operationally in the form of guidance in making decisions to step. Even though morals or humans are more or less often willing to submit to the teachings of religion because science in terms of morality is indeed very little to give guidance if it cannot be said to be nonexistent. Now, on the social side (such as the politicaleconomic law), humans generally often disobey religious teachings for two reasons, namely the study of empirical science is indeed very much and not all religions have guidance on that social problem. Islam clearly has a lot of guidance about the socio-political-economic-law but even then it is often ignored by Muslims themselves. Why? Because more trust / confidence / faith in the products of socio-political scientists that are scattered everywhere even though as explained earlier that these products are many defects. He scientific worldview has generally had a negative impact on other civilizations, and more specifically in the field of epistemology. The term "westernization" is actually another language of "colonialism" because in it there is a program to spread the Western worldview consisting of culture, tradition, values, concepts, systems, religion, beliefs, and so forth. [14] As for intuition, the West in general has narrowed and reduced its meaning only to sensory, emotional, and logical observations which are contemplated by the human mind in which their meanings can suddenly be understood. How ever, all that is just conjecture [15] In a priori analytic a predicate does not add anything new to the subject because it is already contained in it, such as "every object occupies space", whereas in synthetic aposteriori a predicate is related to the subject based on sensory experience because it is stated after having that experience, such as "the table is good ", And in synthetic a priori a knowledge applies generally and absolutely where the element of the ratio as well as the empirical elements needed in it, such as" all events have a cause ". From this, Kant concluded that the third type of decision was the basic requirement for what was called knowledge. [16]

The main problem is that people are often trapped in scientific arrogance so they forget the objectivity of their own behavior and then fall into a structural error. Finally a mistake is made to the wider community which is repeated by the mass media, and finally it becomes a truth. So when the mistake is practiced in social life, such as the form of national policy or legal practice, there is damage in the life of the community. Unfortunately, even though this error is often obvious before the eyes, experts or experts often do not consider it as a result of their mistakes in studying social problems, but instead seek justification for their theories by making partial temporary corrections and ultimately essential truths. not found, and people get worse. That's how humans are with their weaknesses. I review the problem more broadly and deeply in the book above.

\section{Conclusion}

Religion has a correlation with economics where religion as a belief system and practice regulates how people do economic activities. 2. Views of the leaders regarding religion and economics: a. Karl Marx, he saw that religion was used as a tool of exploitation by the capitalists for the proletariat. Religion gives false awareness to its adherents so that they fall asleep in false hopes later. b. Max Weber, sees religion as a dynamic force in which the doctrines contained in religion will determine the economic activity and strength of its adherents. c. Karl Polanyi, observes religion as one of the social 
institutions that has an embeddedness in the economy. Especially in pre-industrial societies their economic activities are based on their attachment to religion. 3. Analysis: the correlation of religion and economics in Islam: a. Islam governs all aspects of the life of his people including in economic life such as zakat, muamalah and faraid. b. Socio-economic ethics in Islam is based on aspects of justice where an economic act must not harm another party. c. Islam encourages its people to become productive human beings but does not violate the limits set by religion. B. Suggestions Economic life in society should always be attached to religious teachings so that harmony and balance in the social life of the community occur.

Acknowledgments. Thank God, the writer always says the presence of Allah SWT. who has the privilege and giving of all the great pleasures, both the blessings of faith, health and strength in the preparation of this paper. Salawat and greetings are always poured out on Sayyidina Muhammad SAW. family and friends and enforcers of His Sunnah until the end of time. On this occasion the authors express their deepest gratitude and highest appreciation to the Supervising Lecturer, on the sidelines of his routine but still take the time to provide instructions, encouragement, advice and direction from the research plan to the completion of writing.

\section{References}

[1] Manusia sebagai Makhluk Individu dan Sosial. 2010.

[2] Abuddin Nata, Metodologi Studi Islam. Jakarta: Raja Grafindo Persada, 2004.

[3] Elizabeth K. Notingham, Agama dan Masyarakat. Jakarta: Rajawali Pers.

[4] Hendi Suhendi, Fiqh Mu'amalah. .

[5] Yusuf Qaradhawi, Sistem Masyarakat Islam dalam Al Qur'an \& Sunnah, Cetak ke 1. Solo: Citra Islami Press, 1997.

[6] Ibid Yusuf Qaradhawi, Sistem Masyarakat Islam dalam Al Qur'an \& Sunnah, Cetak ke 1. Solo: Citra Islami Press, 1997.

[7] Ibid Yusuf Qaradhawi, Sistem Masyarakat Islam dalam Al Qur'an \& Sunnah, Cetak ke 1. Solo: Citra Islami Press, 1997.

[8] Paul B. Horton \& Chester L. Hunt, Sosiologi, Terjemahan Aminudi Ram dan Tita Sobari. Jakarta: Erlangga.

[9] George Ritzer, Teori Sosiologi : Dari Klasik sampai Perkembangan Terakhir Posmodern,. Jakarta: Pustaka Pelajat, 2014.

[10] Beni Ahmad Saebani, Pengantar Antropologi. Bandung: Pustaka Setia, 2012.

[11] Soerjono Soekanto, Sosiologi suatu Pengantar. Jakarta: Rajawali Pers, 2012.

[12] Bustanudin Agus, Agama dalam Kehidupan Manusia: Pengantar Antropologi Agama. Jakarta: Raja Grafindo Persada, 2006.

[13] Damsar \& Indrayani, Pengantar Sosiologi Ekonomi, 3rd ed. Jakarta: Kencana, 2013.

[14] Hamid Fahmy Zarkasyi, Liberalisasi Pemikiran Islam: Gerakan Bersama Missionaris, Orientalis, dan Kolonialis. Ponorogo: CIOS- ISID, 2008.

[15] Syed Muhammad Naquib Al-Attas, Tinjauan Ringkas Peri Ilmu dan Pandangan Alam. Pulau Pinang: Universitas Sains Malaysia, 2006.

[16] Muhammad Muslih, Filsafat Ilmu Kajian atas Asumsi Dasar, Paradigma, dan Kerangka Teori Ilmu Pengetahuan, Cetak Ke 2. Yogyakarta: Bulukar, 2005. 
